\title{
Polynomial relationship of compaction properties of silicate-based RHA modified expansive soil for pavement subgrade purposes
}

Kennedy Chibuzor ONYELOWE - Department of Civil Engineering,

Michael Okpara University of Agriculture, Nigeria - konyelowe@mouau.edu.ng

Michael E. ONYIA - Department of Civil Engineering, Faculty of Engineering, University of Nigeria

Eze R. ONUKWUGHA - Department of Civil Engineering, Faculty of Engineering,

Federal Polytechnic, Nigeria

OscaR C. NNADI - Department of Civil Engineering, Michael Okpara University of Agriculture, Nigeria

IFEANYICHUKWU C. ONUOHA - Department of Environmental Technology,

School of Environmental Sciences, Federal University of Technology, Nigeria

FAZAL E. JALAL - Geotechnical Engineering, Department of Civil Engineering,

Shanghai Jiao Tong University, China

Érkezett: 2020. 02. 01. - Received: 01. 02. 2020. - https://doi.org/10.14382/epitoanyag-jsbcm.2020.36

\section{Abstract}

The effect of varying proportions of rice husk ash (RHA) on the compaction behaviour of modified soil has been investigated under laboratory conditions. Problematic soils exhibit undesirable characteristics that make them unsuitable for use as foundation materials due to their swell shrink properties. Clay dominant in montmorillonite and illite belongs to such group of soil due to the net negative cations at the surface when exposed to moisture. For this reason, such soils are modified in a stabilization process to improve their mechanical properties. In this research series of preliminary studies were carried out and it was discovered that the studied soil has $73.2 \%$ passing number 200 sieve, has liquid limit of $48 \%$ and plasticity index of $19 \%$. This helped to classify the soil as A-7-6 soil according to AASHTO classification method. The soil was also classified as poorly graded soil and highly plastic. The dominant mineral is montmorillonite observed by scanning electron microscopy (SEM) method and due to its high affinity with moisture due to cation exchange, the soil swells and shrinks. The soil was treated with $2 \%$ to $30 \%$ by weight of solid with RHA and the results were observed. The results showed a steady decrease in the maximum dry density (MDD) of the RHA modified soil. The MDD did not reduce beyond the minimum value for clay soil, which is $1.20 \mathrm{~g} / \mathrm{cm}^{3}$. The decrease recorded in MDD was due to smaller specific gravity compared to the soil. Conversely, the optimum moisture content increased due to moulding moisture demand of the isomorphic net negative cation exchange. Though the cementing property of the RHA was due to the silicate-based aluminosilicates that provided bonding of the treated material, the blend will need a filler material to achieve a more appropriate densification. Finally, mathematical relationships of a polynomial form were proposed that summarized the total compaction behaviour of the RHA modified soil.

Keywords: polynomial relationship, compaction, silicate-based materials, rice husk ash, recycled solid waste material, composite construction materials

Kulcsszavak: polinomiális kapcsolat, tömörítés, szilikátalapú anyagok, rizshéj pernye, újrahasznosított hulladékanyagok, kompozik építôanyagok

\section{Introduction}

Road traffic is carried by the pavement, which in engineering terms is a horizontal structure supported by in situ natural material [1-4]. In order to design this structure, existing records must be examined and subsurface explorations also conducted [1]. The engineering properties of the in-situ soil are established, particularly with respect to strength, stiffness, durability, susceptibility to moisture, and propensity to shrink and swell over time [3-6]. The relevant properties are determined either by field tests (typically by measuring deflection under a loaded plate or the penetration of a rod), by empirical estimates based on the soil type, or by laboratory measurements [2]. The material is tested in its weakest expected condition, usually at its highest probable moisture content [5].
Kennedy C. ONYELOWE

He is a senior lecturer at the MOUAU, Nigeria, AE-FUNAI, Abakaliki, Nigeria and

External Proposal Technical Reviewer, RIF, Makerere University, Uganda. His research interests include Geotechnical and Geoenvironmental Engineering. He is a member of several professional societies.

Michael ONYIA He is a senior lecturer at the UNN, Nigeria and former head of department of Civil Engineering. His research interests include, structural engineering, materials engineering and geoenvironmental engineering.

Eze R. ONUKWUG HA He is a chief lecturer and director at the FedPoNek, Owerri and

his research interest is in water resources and environmental engineering

Oscar C. NNADI He is a graduate student of the department of civil engineering, MOUAU, Nigeria with research focus in Geotechnical Engineering.

Ifeanyichukwu C. ONUOHA He is a doctoral candidate of the Department of Environmental Technology, FUTO, Nlgeria with a research background in soil remediation and green and sustainable construction materials.

Fazal E. JALAL He is a doctoral student of Shanghai Jiao Tong University, China with a research focus on artificial intelligence in geotechnical engineering.
Probable performance under traffic is then determined [2]. Soils unsuitable for the final pavement are identified for removal, suitable replacement materials are earmarked, the maximum slopes of embankments and cuttings are established, the degree of compaction to be achieved during construction is determined, and drainage needs are specified [1]. However, in the case of problematic soils with undesirable characteristic, there has always been a standard need to modify the soils to improve the engineering properties required for a stable and durable foundation $[7,8]$. Binders are the commonest in this effort, utilized to improve the quality of weak engineering soils [9]. Materials that exhibit such binding properties are known for either their calcium oxide content or silicate-based components like the rice husk ash (RHA) [10-13]. 
RHA is a primary agricultural product obtained from paddy. Rice milling produces a by-product known as husk which is surrounded by the paddy grain [14-16]. At the time of milling of paddy about $78 \%$ of weight constitutes rice, broken rice, bran and the remaining $22 \%$ of the weight of paddy is received as husk. For every $40 \mathrm{~kg}$ of rice $10 \mathrm{~kg}$ of husk is produced. The husk is disposed by dumping it heap in an open area near the mill or on the sides of the road to be burnt later [5]. Burning the rice husk produces about $15-20 \%$ weight of ash [5]. As the ash is very light, it is easily carried away by wind and water causing air pollution and water pollution $[5,6]$. The large quantity of ash produced requires maximum areas for disposal. The husk is converted to ash by the process of incineration. The husk is generally used as fuel in the rice mills to produce steam for boiling. It contains about $75 \%$ of organic volatile matter and the rest $25 \%$ of the weight of the husk is converted into ash known as RHA during the burning process. This RHA in turn contains about $85 \%$ - $90 \%$ of amorphous silica. The maximum percentage of siliceous material contained in RHA showed that it has pozzolanic properties. Hence for every $997.9 \mathrm{~kg}$ of paddy milled, about $217.7 \mathrm{~kg}$ (22\%) of husk is produced, and when it is fired in the boilers, about $54.4 \mathrm{~kg}(25 \%)$ of RHA is generated. This RHA is a great environmental hazard causing a negative impact on the land and the surrounding area in which it is dumped. There are many ways that are being thought for disposing it by making a commercial use with RHA. In the field of geo-environmental engineering, RHA has been found as a suitable geomaterial utilized in soil treatment due to its high composition of aluminosilicates [17-22]. Compaction characteristics of a test problematic soil treated with RHA was studied in this research making use of compaction curves (see Fig. 1) to propose relationships with the added binding material.

Compaction curves are invariable curves of polynomial function. A polynomial function is an equation with multiple terms that has variables and exponents. A graph of polynomial function contains a great deal of information which we can obtain the information by looking at the graph and equation. We can obtain the end behaviour of the graph if given the information or equation. By looking at the graph, we can determine the end behaviour, real and non-real zeros; if the graph is odd or even and the relative extrema. The end behaviour of a graph (compaction curve) is what is happening to the $y$-values (dry density) as the $\mathrm{x}$-value (water content) increases and decreases.

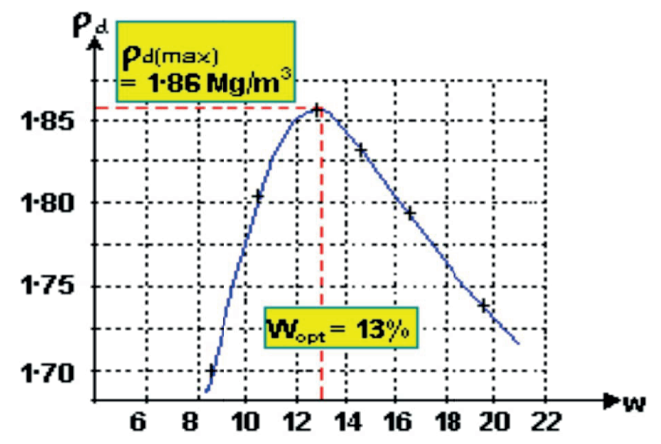

Fig. 1 A typical compaction curve [23]

1. ábra Tipikus tömörödési görbe [23]
When an expansive soil is densified under a constant compactive effort but with varying moisture content, a typical dry density versus water content relationship develops. The shape of the compaction curve is related strongly to the particle size distribution of the soil and compaction method utilised [24]. Compaction curves of expansive soils are essential to establish practical and reliable criteria for effective control of field compaction on most projects.

\section{Materials and methods}

\subsection{Materials preparation}

\section{Soil}

The test expansive soil was collected from Nbawsi, Nigeria located on $5^{\circ} 23^{\prime} 00^{\prime \prime} \mathrm{N}$ and $7^{\circ} 26^{\prime} 00^{\prime \prime} \mathrm{E}$ and on military grid reference system coordinates of 32NLL2641295260. $200 \mathrm{~g}$ of the sample was collected and prepared for use in the laboratory investigation.

\section{Rice husk ash}

Rice husk was collected from rice mills and local dumpsites in Abakaliki, Ebonyi State, Nigeria where the rice farming and milling is the most common occupation. These waste materials were sun dried and combusted to derive ash known as rice husk ash (RHA). The ash was then stored for use in the stabilization experiment.

\subsection{Experimental methods}

The basic tests that were conducted on the test soil for characterization and classification reasons are as follows:

- Particle size distribution (PSD): this was conducted with vertically arranged sieve sizes mounted on an automatic shaker in accordance with BS 1377-2 and Nigerian General Specification $[25,26]$.

- Consistency limits: this was conducted using a 2013 cassagrande apparatus on the untreated soil in accordance with BS 1377-2, and NGS [25, 26].

- Specific gravity test was conducted by pycnometer method in accordance with BS 1377-2, and NGS [25, 26].

- Chemical oxides composition test on the test soils and the test materials with XRF method in accordance with BS 1377-2 and Nigerian NGS [25, 26].

- California bearing ratio test (CBR) was conducted on the untreated and treated soils blended with. This was experimented with a 2015 S211 KIT CBR penetration machine, motorized $50 \mathrm{kN}$ ASTM used to load the penetration piston into the soil sample at a constant rate of $1.27 \mathrm{~mm} / \mathrm{min}(1 \mathrm{~mm} / \mathrm{min}$ to BS Spec.) and to measure the applied loads and piston's penetrations at determined intervals with which CBR values were computed using Eq. (1) and results were obtained. This was experimented in accordance with British standards and AASHTO methods $[1-4,25,26,27]$. 
$C B R=\frac{P_{T}}{P_{S}} x 100$

Where;

$P_{T}=$ corrected unit test load corresponding to the chosen penetration from load penetration curve, $P_{T}=$ the total standard load for the same depth of penetration which can be taken as $13.24 \mathrm{kN}$ for $2.5 \mathrm{~mm}$ penetration and $19.96 \mathrm{kN}$ for 5.0 $\mathrm{mm}$ penetration.

- And finally, standard Proctor compaction test was conducted on the untreated soil with 2016 ELE

Automatic Compactor Machine in accordance with BS 1377-2, and NGS $[25,26]$ and on the rice husk ash modified soil in accordance with BS 1924 [27]. The rice husk was added and mixed with the soil in the proportion of 2 to $30 \%$ in increments of $2 \%$.

\section{Results and discussions}

\subsection{General behavior and classification of test materials}

The preliminary tests conducted on the test materials were to enable a proper characterization of the materials and the basic classification protocol in a laboratory exercise. Figs. 2-5 show the graphical results of the basic tests on the soil for particle size distribution, Atterberg limits, compaction and California bearing ratio. Results of the fundamental experiments show that the soil is classified as an A-7-6 soil according to AASHTO grouping. This classification is due to the fact that the percentage passing the number 200 sieve is greater than $36 \%$ (73.2\%), the liquid limit of the soil is greater than $41 \%$ (48\%) with a plasticity index greater than $11 \%(19 \%)$ and also a poorly graded soil (GP) according to the USCS. The soil is considered a silt-clay soil because more than $35 \%$ of the test specimen passed $0.0075 \mathrm{~mm}$ sieve. Generally, the soil is considered fair to poor in the rating for use as a subgrade material in accordance with AASHTO minimum requirements. Table 1 shows the general information table for the classification data of the test soil and the additive which is rice husk ash. Table 2 shows the chemical oxide composition of the test materials including those of ordinary Portland cement made by Dangote Industries to show the component differences between ordinary cement and rice husk ash. It can also be deduced from Table 2 that rice husk ash derives its cementing properties from the silicatebased component of the ash as against the cement that derives its cementing property from calcium oxide (lime). It has been shown that the silicate composition in the rice husk ash is about $86 \%$ against about $64 \%$ lime present in ordinary cement. This high content of silicates contained in RHA is responsible for the cementitious ability of RHA when used to modify soils in a stabilization exercise. Sadly, the high content of sodium oxide present in the test soil is responsible for the soil's expansive and plastic behaviour. This contributes to the problematic behaviour, which soil exhibits that makes it unsuitable for use as subgrade material in pavement construction. However, this necessitated the stabilization exercise conducted with the rice husk ash to improve and modify the soil to make it more suitable for use as a pavement underlain.

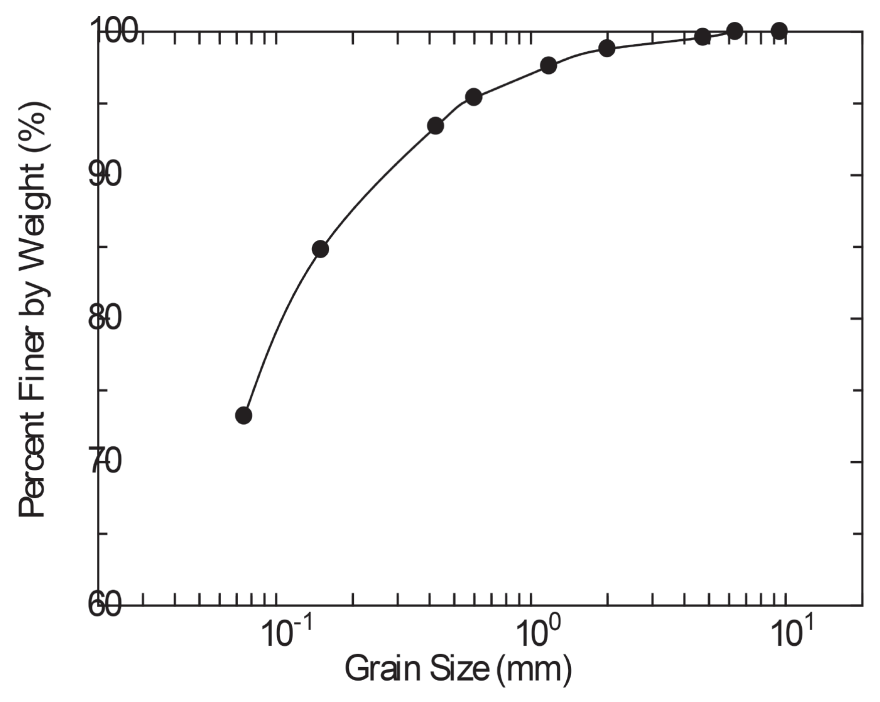

Fig. 2 Grain size distribution of study soil

2. ábra A vizsgált talaj szemcseméret-eloszlása

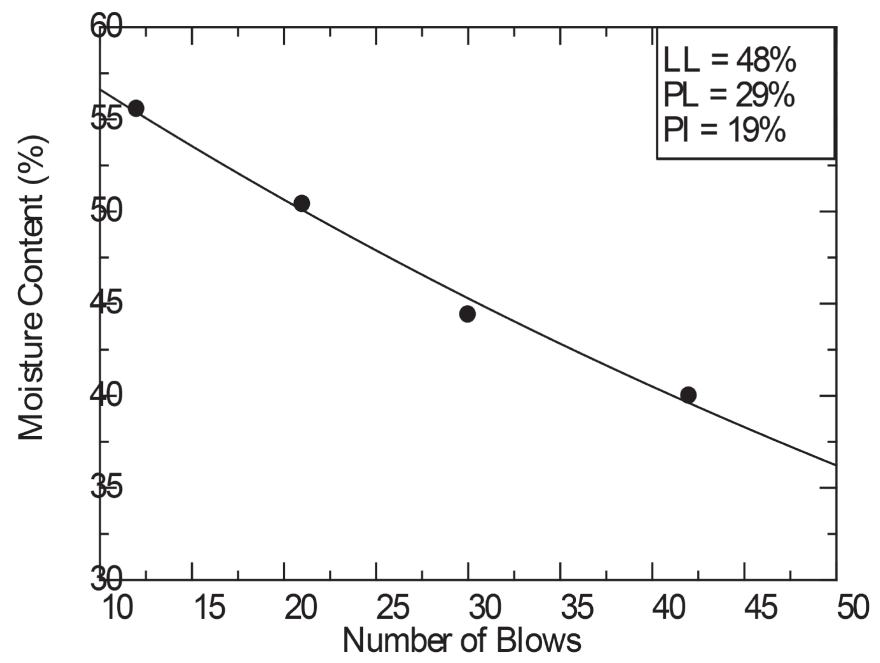

Fig. 3 Atterberg limits curve of the study soil

3. ábra A vizsgált talaj Atterberg határgörbéje

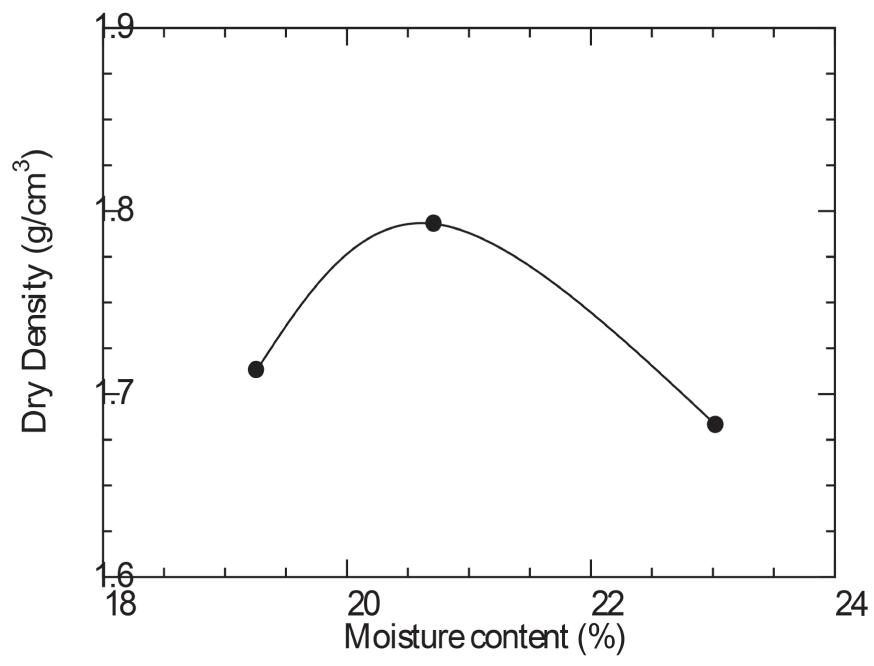

Fig. 4 Compaction curve of the study soil

4. ábra A vizsgált talaj tömörödési görbéje 


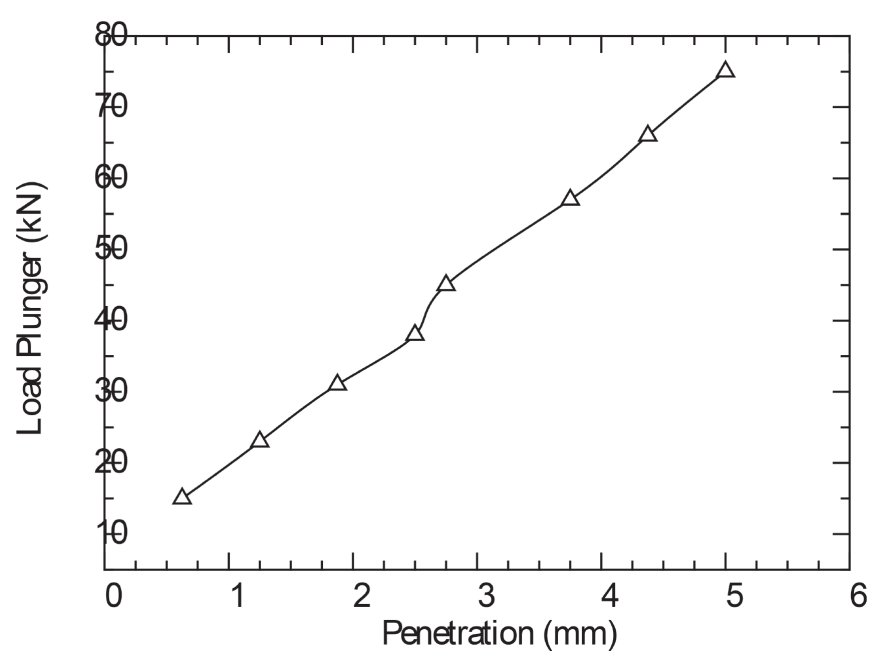

Fig. 5 California bearing ratio behaviour of study soil 5. ábra A vizsgált talaj kaliforniai teherbírási értékei

\begin{tabular}{|cc|}
$\begin{array}{c}\text { Property description of test } \\
\text { soils and units }\end{array}$ & Values \\
\hline \% Passing sieve No. 200 & 73.2 \\
NMC (\%) & 19 \\
LL (\%) & 48 \\
PL (\%) & 29 \\
PI (\%) & 19 \\
$G_{S}$ & 2.74 \\
$G_{S}(r h a)$ & 2.01 \\
AASHTO Classification & $\mathrm{A}-7-6(14)$ \\
UCSC & $\mathrm{GP} / \mathrm{Cl}$ \\
MDD (g/cm $\left.{ }^{3}\right)$ & 1.80 \\
OMC (\%) & 20.72 \\
CBR (\%) & 40.6 \\
Predominant Mineral & montmorillonite \\
Colour & reddish brown
\end{tabular}

Table 1 Basic properties of test soils

1. táblázat A vizsgált talaj alapvetö tulajdonságai

\subsection{Compaction behaviour of rice husk ash modified soil}

The RHA was mixed with 2 to $30 \%$ in increment of $2 \%$ by weight of the solid with the soil and the behaviour of the soil with the increased proportion of the additive was observed. Fig. 6 shows the dry density behaviour achieved at optimum moisture contents of the treated soil. From the graph, it can be deduced that the maximum dry density of the treated soils reduced with increase in the rice husk ash proportion while the moisture content increased as well (see Figs. 7 and 8 ). The increase in optimum moisture content was due to the increased hydration reaction with the increased addition of rice husk ash with its high content of aluminosilicates [10, 28]. This is also due to water penetrating the interlayer molecular spaces and concomitant adsorption [10]. Also, this is equally due largely to the type of exchangeable cations contained in the reactive interface between the clay soil and the rice husk ash mixed with moulding moisture [29-31]. The dry density reduced due to the fact that the specific gravity of RHA is less than that of soil. From, Fig. 7, a polynomial relationship has been proposed to monitor the behaviour of maximum dry density with respect to the proportions of rice husk ash. The polynomial relationship shows the parabolic behaviour of the studied soil when treated with rice husk as compacted at optimum moisture. These relationships are presented in Eq. 1 and 2 where $Y$ represents both the maximum dry density and optimum moisture content in Figs. 7 and 8.

$\mathrm{MDD}=-0.001 \mathrm{RHA}^{2}-0.0124 \mathrm{RHA}+1.7699$

$\mathrm{OMC}=0.0186 \mathrm{RHA}^{2}-0.1722 \mathrm{RHA}+20.806$

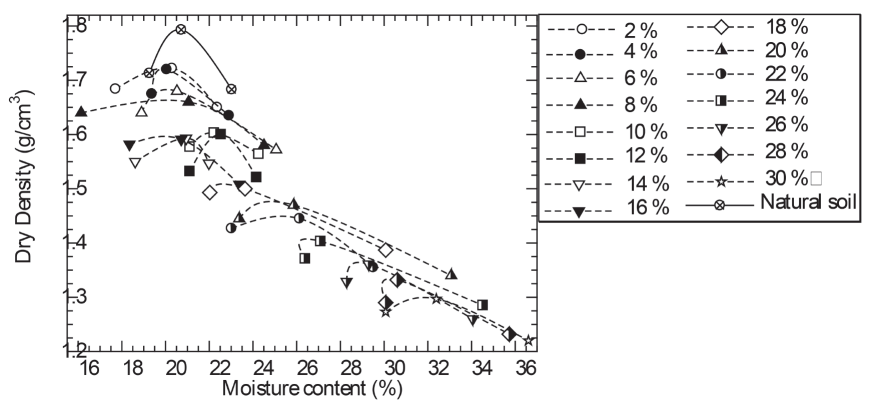

Fig. 6 Compaction curves relationship of rice husk ash modified soil 6. ábra A rizshéj pernye tartalom hatása a vizsgált talaj tömörödésére

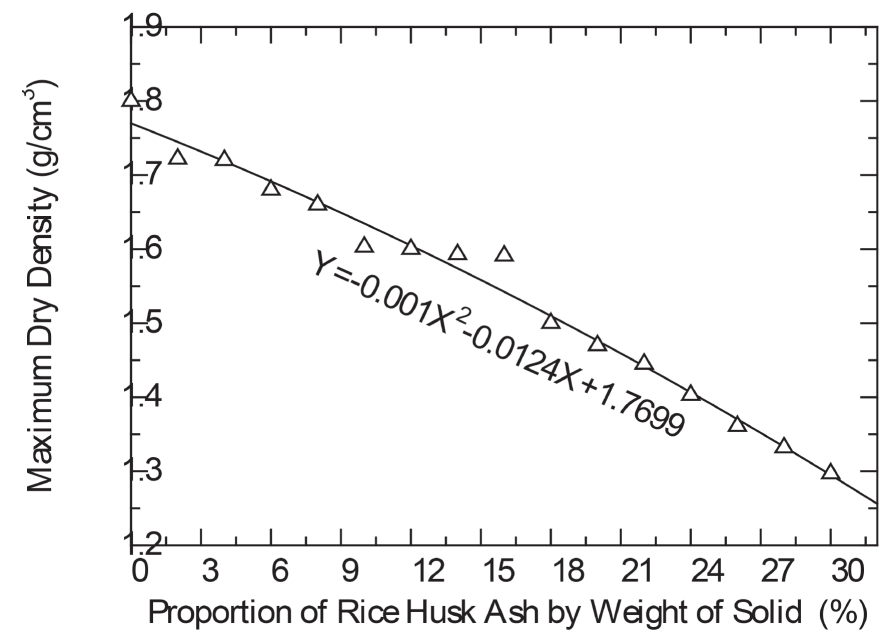

Fig. 7 Maximum dry density relationship with varying proportions of rice husk ash 7. ábra A rizshéj pernye tartalom hatása a maximális száraz sürüségre

\begin{tabular}{|c|c|c|c|c|c|c|c|c|c|c|c|c|c|}
\hline \multirow{2}{*}{ Materials } & \multicolumn{13}{|c|}{ Oxides composition (content wt \%) } \\
\hline & $\mathrm{SiO}_{2}$ & $\mathrm{Al}_{2} \mathrm{O}_{3}$ & $\mathrm{CaO}$ & $\mathrm{Fe}_{2} \mathrm{O}_{3}$ & MgO & $\mathrm{K}_{2} \mathrm{O}$ & $\mathrm{Na}_{2} \mathrm{O}$ & $\mathrm{TiO}_{2}$ & LOI & $\mathrm{P}_{2} \mathrm{O}_{5}$ & $\mathrm{SO}_{3}$ & IR & Free CaO \\
\hline study soil & 40.06 & 15.09 & 2.30 & 8.66 & 5.89 & 12.1 & 10.4 & - & - & 5.5 & - & - & - \\
\hline RHA & 86.0 & 3.3 & 3.6 & 3.2 & 0.45 & - & - & - & 3.45 & - & - & - & - \\
\hline DOPC & 21.45 & 4.45 & 63.81 & 3.07 & 2.42 & 0.83 & 0.20 & 0.22 & 0.81 & 0.11 & 2.46 & 0.16 & 0.64 \\
\hline
\end{tabular}


The maximum dry density of the treated soil was at its lowest value at $30 \%$ by weight addition of RHA to the soil, which is $1.297 \mathrm{~g} / \mathrm{cm}^{3}$, a value still within the standard minimum value for clay soils $\left(1.20 \mathrm{~g} / \mathrm{cm}^{3}\right)$. The $E q .1$ with $\mathrm{R}^{2}$ equals 0.997 can be used to monitor the behaviour of the test soil when modified with RHA for the purpose of subgrade construction. However, RHA would require the assistance of another additive with higher specific gravity to achieve higher densification.

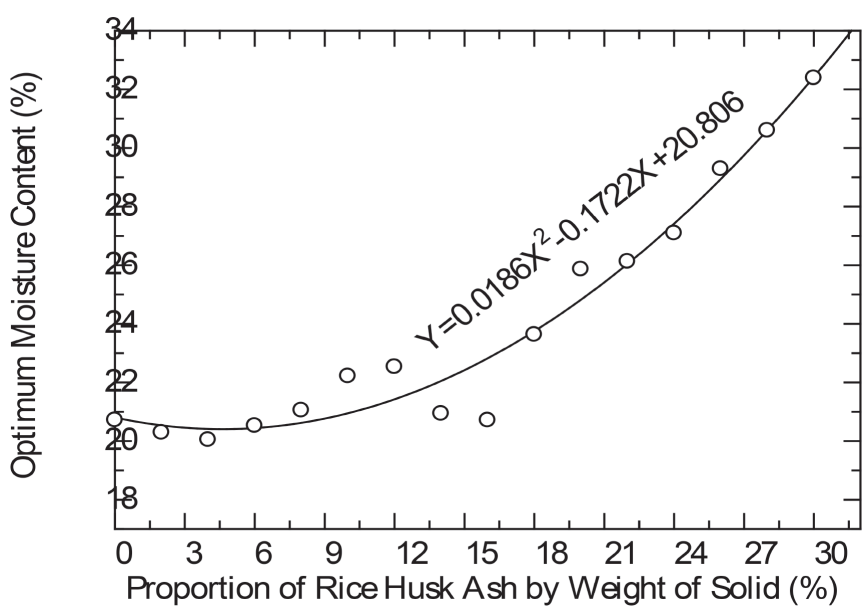

Fig. 8 Optimum moisture condition relationship of modified soil with varying proportion of rice husk ash

8. ábra A rizshéj pernye tartalom hatása a vizsgált talajok optimális nedvességtartalmára

\section{Conclusion}

The compaction characteristics of RHA modified expansive soil were studied in the laboratory and the following remarks can be made;

- The rice husk ash was observed to exhibit pozzolanic properties and served as a supplementary cementing material.

- The test soil was observed after preliminary experiments that it contains montmorillonite as the dominant mineral, which is responsible for the problematic nature of the soil due to its affinity with moisture.

- The blend of soil and rice husk ash in the modification exercise showed a decrease in the MDD of the treated soil and an increase in the OMC. This was due to the less specific gravity of the ash compared to that of the test soil and affinity for moisture in the hydration reaction that increased the OMC substantially. The silicates-based composition of the ash contributed to the pozzolanic reaction and enhanced the formation of flocs due to cation exchange of the isomorphous particles of the ash within the adsorbed complex phase.

- The RHA showed to be a good construction material to serve as a supplementary cementitious material because of its aluminosilicates content.

- The MDD polynomial relationship with the added admixture produced a correlation of 0.997 and this shows a good fit for the equation to be used in the design of stabilization experiments where RHA is utilized as a binder.

\section{References}

[1] AASHTO (1993). Guide for Design of Pavement Structures. American Association of State Highway and Transportation Officials (AASHTO), Washington DC.

[2] AASHTO (2005). Standard Specification for Transportation Materials and Methods of Sampling and Testing, Part II Methods of Sampling and Testing $25^{\text {th }}$ Edition. American Association of State Highway and Transportation Officials, Washington DC.

[3] AASHTO T 190-09 (2014). Standard method of test for resistance R-value and expansion pressure of compacted soils. American Association of State Highway and Transportation Officials, Washington DC.

[4] AASHTO T 307 (2014). Standard method of test for determining the resilient modulus of soils and aggregate materials. American Association of State Highway and Transportation Officials, Washington DC.

[5] Onyelowe, K. C. - Bui Van, D. - Eberemu, A. O. - Xuan, M. N. - Salahudeen, A. B. - Ezugwu, C. - Van, M. N. - Orji, F. - Sosa, F. - Duc, T. T. - Amhadi, T. - Ikpa, C. - Ugorji, B. "Sorptivity, swelling, shrinkage, compression and durability of quarry dust treated soft soils for moisture bound pavement geotechnics". Journal of Materials Research and Technology, 8(4), 2019, 3529-3538. https://doi.org/10.1016/j.jmrt.2019.06.029

[6] Onyelowe, K. C. - Amhadi, T. - Ezugwu, C. N. - Onukwugha, E. Ugwuanyi, H. - Jideoffor, I. - Ikpa, C. - Iro, U. - Ugorji, B. : Cemented Lateritic Soil as Base Material Improvement Using Compression. In book: Innovative Infrastructure Solutions using Geosynthetics, Proceedings of the 3rd GeoMEast International Congress and Exhibition, Egypt 2019 on Sustainable Civil Infrastructures - The Official International Congress of the Soil-Structure Interaction Group in Egypt (SSIGE), 2020c, pp. 58-67. https://doi.org/10.1007/978-3-030-34242-5_4

[7] Onyelowe, K. C. - Salahudeen, A. B. - Eberemu, A. O. - Ezugwu, C. N. - Amhadi, T. - Alaneme, G. : Oxides of Carbon Entrapment for Environmental Friendly Geomaterials Ash Derivation. In book: Recent Thoughts in Geoenvironmental Engineering, Proceedings of the 3rd GeoMEast International Congress and Exhibition, Egypt 2019 on Sustainable Civil Infrastructures - The Official International Congress of the Soil-Structure Interaction Group in Egypt (SSIGE), 2020a, pp. 58-67. https://doi.org/10.1007/978-3-030-34199-2_4

[8] Onyelowe, K. C. - Salahudeen, A. B. - Eberemu, A. O. - Ezugwu, C. N. - Amhadi, T. - Alaneme, G. - Sosa, F.: Utilization of Solid Waste Derivative Materials in Soft Soils Re-engineering. In book: Recent Thoughts in Geoenvironmental Engineering, Proceedings of the 3rd GeoMEast International Congress and Exhibition, Egypt 2019 on Sustainable Civil Infrastructures - The Official International Congress of the Soil-Structure Interaction Group in Egypt (SSIGE), 2020b, pp. 49-57. https://doi.org/10.1007/978-3-030-34199-2_3

[9] American Standard for Testing and Materials (ASTM) C618 (2014). Specification for Pozzolanas. ASTM International, Philadelphia, USA.

[10] Kotova, O. B. - Shushkov, D. A. - Gömze, L. A. - Kurovics, E. - Ignatiev, G. V. - Sitnikov, P. A. - Ryabkov, Y. I. - Vaseneva, I. N.: Composite materials based on zeolite-montmorillonite rocks and aluminosilicate wastes. Epitő anyag - Journal of Silicate Based and Composite Materials, Vol. 71 (4), 2019, Pp. 125-130. https://doi.org/10.14382/epitoanyag-jsbcm.2019.22

[11]El-Fakharany, M. E. - Ezzat, M. - Gad, A. - Ghafour, N. G. Abdel Baghdady, A. R.: Performance of dolomitic cementitious mortars as a repairing material for normal concrete in Egypt. Építő anyag - Journal of Silicate Based and Composite Materials, Vol. 71 (2), 2019, Pp. 33-42. https://doi.org/10.14382/epitoanyag-jsbcm.2019.7

[12] Bui Van, D. - Onyelowe, K. C. - Phi Van Dang - Dinh Phuc Hoang Nu Nguyen Thi - Wu, W. (2018). Strength Development of Lateritic Soil Stabilized by Local Nanostructured Ashes, Proceedings of China-Europe Conference On Geotechnical Engineering, SSGG, pp. 782-786, 2018. https://doi.org/10.1007/978-3-319-97112-4_175

[13] Edeh, Joseph Ejelikwu - Eberemu, Adrian Oshioname - Arigi, Abraham S. D. (2012). Reclaimed Asphalt Pavement Stabilized Using Crushed Concrete Waste as Highway Pavement Material, Advances in Civil Engineering Materials, 1 (1), 1-14, https://doi.org/10.1520/ACEM20120005.

[14] Little, D.N. - Males, E. H. - Prusinski, J. R. - Stewart, B. (2010). Cementitious Stabilization; Transportation in the New Millennium, Louisiana, USA, pp. 1-7. 
[15] Janathan, Q. A. - Sanders, T. G. - Chenard, M. (2004). Road Dust Suppression; Effect on Unpaved Road Stabilization, JEST, Malaysia, vol. 1, pp. 21

[16.] Hasan, M. M. - Islam, M. R. - Tarefder, R. A. (2018). Characterization of subgrade soil mixed with recycled asphalt pavement. Journal of Traffic and Transportation Engineering, Vol. 5 (3), pp. 207-214. https://doi.org/10.1016/j.jtte.2017.03.007

[17] Onyelowe, K. C. (2012). Soil Stabilization Techniques and Procedures; A Clue for the Developing world-Nigeria, Global Journal of Engineering and Technology, GJET, India. Vol.5 (1) 65-69.

[18] Onyelowe, K. C. (2012). Geochemistry of Soil Stabilization, ARPN Journal of Earth Sciences, Vol. 1, Issue 2, Pp. 32-35.

[19] Onyelowe, K. C. - Okafor, F.O. (2013). Portland Cement/Quarry Dust Improvement of Olokoro Laterite for Road Base, World Journal of Engineering Science WJES, India. 1(4)133-143.

[20] Onyelowe, K. C. - Ubachukwu, O. A. (2015). Stabilization of OlokoroUmuahia Lateritic Soil using Palm Bunch Ash (PBA) as Admixture, Umudike Journal of Engineering and Technology (UJET), Volume 1, Number 2, Pp. 67-77.

[21] Onyelowe, K. C. (2017). Solid Wastes Management (SWM) in Nigeria and their Utilization in the Environmental Geotechnics as an Entrepreneurial Service Innovation (ESI) for Sustainable Development. Int J Waste Resour 7: 282. ISSN: 2252-5211.

[22] Onyelowe, K. C. - Maduabuchi M. N. (2017). Palm Bunch Management and Disposal as Solid Waste and the Stabilization of Olokoro Lateritic Soil for Road Construction Purposes in Abia State, Nigeria. Int J Waste Resour Vol 7 Issue 2. https://doi.org/10.4172/2252-5211.1000279

[23] Onyelowe, K. C. - Duc Bui Van - Igboayaka, Clifford - Orji, Francis Ugwuanyi, Henry (2018). Rheology of mechanical properties of soft soil and stabilization protocols in the developing countries-Nigeria. Materials Science for Energy Technologies.

https://doi.org/10.1016/j.mset.2018.10.001

[24] Onyelowe, K. C. - Bui Van, D. (2018). Predicting Strength Behaviour of Stabilized Lateritic Soil- Ash Matrix using Regression Model for
Hydraulically Bound Materials Purposes, International Journal of Pavement Research and Technology.

https://doi.org/10.1016/j.ijprt.2018.08.004

[25] BS 1377 - 2, 3, (1990). Methods of Testing Soils for Civil Engineering Purposes, British Standard Institute, London.

[26] Nigeria General Specification/Federal Ministry of Works and Housing (1997). Testing for the selection of soil for roads and bridges, Vol. II.

[27] BS 1924, (1990). Methods of Tests for Stabilized Soil, British Standard Institute, London.

[28] Bui Van, D. - Onyelowe, K. (2018). Adsorbed complex and laboratory geotechnics of Quarry Dust (QD) stabilized lateritic soils. Environmental Technology \& Innovation, 10, 355-363. https://doi.org/10.1016/j.eti.2018.04.005

[29] Salahudeen, A. B. - Eberemu, A. O. - Osinubi, K. J., (2014). Assessment of Cement Kiln Dust-Treated Expansive Soil for the Construction of Flexible Pavements. Geotechnical and Geological Engineering, an International Journal, 32:923-931. https://doi.org/10.1007/s10706-014-9769-0

[30] Szabó R. 2019. Control of mechanical properties of lignite fly ash based geopolymers by vibrating compression. Építő anyag - Journal of Silicate Based and Composite Materials, Vol. 71 (2), 2019, Pp. 66-71. https://doi.org/10.14382/epitoanyag-jsbcm.2019.12

[31] Khater, Hisham Mustafa Mohamed: Preparation and characterization of lightweight geopolymer composites using different aluminium precursors. Építőanyag - Journal of Silicate Based and Composite Materials, Vol. 70 (6), 2018, Pp. 186-194. https://doi.org/10.14382/epitoanyag-jsbcm.2018.33

Ref.:

Onyelowe, Kennedy Chibuzor - Onyia, Michael E. - Onukwugha, Eze R. - Nnadi, Oscar C. - Onuoha, Ifeanyichukwu C. - Jalal, Fazal E.: Polynomial relationship of compaction properties of silicate-based RHA modified expansive soil for pavement subgrade purposes Építőanyag - Journal of Silicate Based and Composite Materials, Vol. 72, No. 6 (2020), 223-228. p.

https://doi.org/10.14382/epitoanyag-jsbcm.2020.36
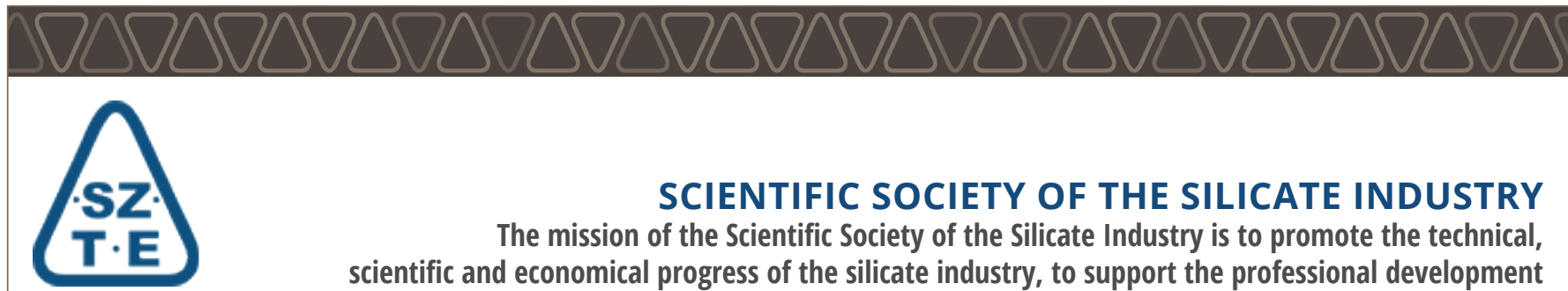

\section{SCIENTIFIC SOCIETY OF THE SILICATE INDUSTRY}

The mission of the Scientific Society of the Silicate Industry is to promote the technical, scientific and economical progress of the silicate industry, to support the professional development and public activity of the technical and economic experts of the industry.

We represent the silicate industry in activities improving legal, technical and economic systems We establish professional connections with organizations, universities and companies abroad We help the young generation's professional education and their participation in public professional activities
We ensure the continuous development of experts from the silicate industry by organizing professional courses

We promote the research and technological development in the silicate industry

We organize scientific conferences to help the communication within the industry
THE SGOENTUFIC SOGUETY OF TME

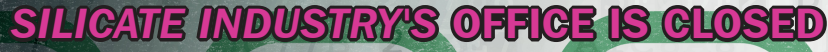
Due to the spread of corronavtrus the Society's office is closed for funtherp of tices We adjourn all of our events for that thmes

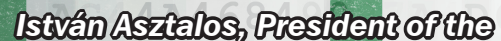
scientifite society op the sticate lodurstry
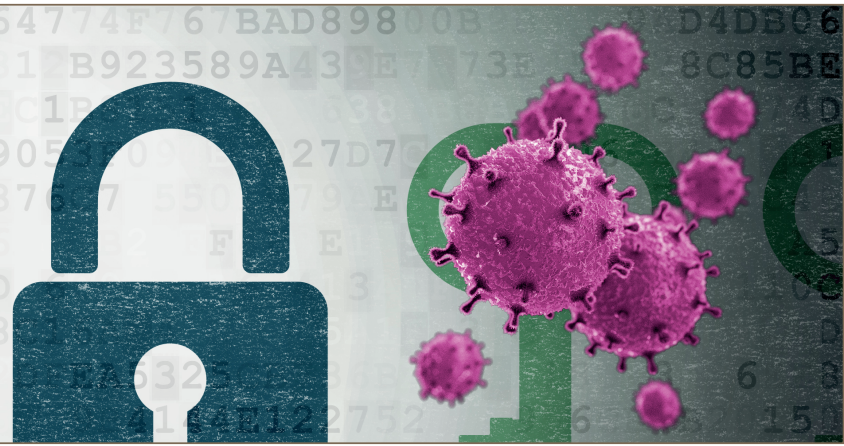